\title{
Vanadium Extraction from Molten Vanadium Slag with High Ca and P Contents by Direct Oxidation-acid Leaching Method
}

\author{
Y.N. WANG, W.C. Song \& H. Li \\ School of Metallurgical and Ecological Engineering, University of Science and Technology Beijing, Beijing \\ 100083, China
}

\begin{abstract}
A novel method of extracting vanadium from molten vanadium slag was developed to process vanadium slag with high $\mathrm{Ca}$ and $\mathrm{P}$ contents. The mineral phases of the clinker obtained after oxidizing the molten vanadium slag with high $\mathrm{Ca}$ and $\mathrm{P}$ contents $\left(10.71\right.$ wt. $\% \mathrm{~V}_{2} \mathrm{O}_{3}, 19.20$ wt. \% $\mathrm{CaO}, 1.03$ wt. \% $\left.\mathrm{P}_{2} \mathrm{O}_{5}\right)$ were analyzed by X-ray diffraction (XRD) to fully comprehend the compositions of the clinker. The leaching conditions of extracting vanadium from the clinker and the kinetics during the leaching process were also investigated in this paper in order to obtain a better leaching rate of vanadium. The results indicate that most of $\mathrm{V}$ in the clinker exists in the form of calcium orthovanadate $\left(\mathrm{Ca}_{3} \mathrm{~V}_{2} \mathrm{O}_{8}\right)$, and the rest turns into the vanadate with low valence state of $\mathrm{V}$. Silicates mainly include pyroxene $\left(\mathrm{Ca}(\mathrm{Mg} / \mathrm{Fe} / \mathrm{Ca}) \mathrm{Si}_{2} \mathrm{O}_{6}\right)$, calcium silicoaluminate $\left(\mathrm{CaAl}_{2} \mathrm{Si}_{2} \mathrm{O}_{8}\right)$ and calcium orthosilicate $\left(\mathrm{Ca}_{2} \mathrm{SiO}_{4}\right)$. $\mathrm{P}$ exists in the form of calcium phosphate $\left(\mathrm{Ca}_{3}\left(\mathrm{PO}_{4}\right)_{2}\right)$. The leaching rate of vanadium can reach $95 \%$ under the conditions: sulfuric acid concentration of $15 \%$, liquid to solid ratio of $5: 1 \mathrm{~mL} / \mathrm{g}$, leaching temperature of $90^{\circ} \mathrm{C}$, leaching time of $40 \mathrm{~min}$, stirring rate of $240 \mathrm{r} / \mathrm{min}$. Kinetic analysis results show that the acid leaching process of the clinker can be well interpreted by the unreacted shrinking core model under internal diffusion control, and the apparent activation energy is 8.36 $\mathrm{kJ} / \mathrm{mol}$.
\end{abstract}

KEYWORD: Molten vanadium slag with high $\mathrm{Ca}$ and $\mathrm{P}$ contents; vanadium extraction; phase; leaching; kinetics

\section{INTRODUCTION}

At present, vanadium extraction from vanadium containing hot metal is mainly accomplished in the converter process in China (Fu, 2011). During the process, vanadium is oxidized and enriched in the slag. After that, semi-steel and vanadium slag are obtained, then the vanadium slag as raw materials for vanadium extraction is processed through hydrometallurgical method to recover vanadium. At the end of the converter process, an acid slag system with complicated multi-component is formed (Zhang et al., 2011), which is not favorable for dephosphorization from vanadium containing hot metal. In addition, the work of removing phosphorus also could not be finished effectively during the following semi-steel blowing process (Dong, 1997). In order to settle this problem, a method of adding $\mathrm{CaO}$ containing materials to form basic slag to extract vanadium and remove phosphorus simultaneously from vanadium containing hot metal is put forward, and a better outcome of phosphorus removal in the previous experiment has been achieved. In this case, a new kind of vanadium slag that contains more $\mathrm{CaO}$ and $\mathrm{P}_{2} \mathrm{O}_{5}$ contents is obtained, and such type slag is defined as vanadium slag with high $\mathrm{Ca}$ and $\mathrm{P}$ contents for the following discussion.

The $\mathrm{V}_{2} \mathrm{O}_{3}$ content in the vanadium slag with high $\mathrm{Ca}$ and $\mathrm{P}$ is generally 9.0 wt. \% 13.0 wt. \%, between the content in the original vanadium slag (15.0 wt. \% 20.0 wt. \%) and that in the vanadium bearing steel slag (about 3.0 wt. \%). The $\mathrm{CaO}$ and $\mathrm{P}_{2} \mathrm{O}_{5}$ contents in the vanadium slag with high $\mathrm{Ca}$ and $\mathrm{P}$ are approximately 8.0 wt. $\% \sim 28.0$ wt. $\%$ and 0.6 wt. \% 1.3 wt. \%, respectively, and much higher than their contents in the original vanadium slag (3.0 wt. $\% \mathrm{CaO}$ and 0.2 wt. $\% \mathrm{P}_{2} \mathrm{O}_{5}$ ). "A method of dealing with vanadium slag with energy conservation and emission reduction" was proposed by University of Science and Technology Beijing (Li et al., 2012; Song et al., 2013, 2014; Li et al., 2013) considering the fact that the current roasting process for vanadium extraction is not suitable for dealing with such type vanadium slag. The main phases of the clinker and the acid leaching conditions of vanadium extraction were investigated, and the kinetics analysis was also performed in this paper 


\section{EXPERIMENTAL}

The vanadium slag with high $\mathrm{CaO}$ and $\mathrm{P}$ contents was prepared by mixing the original slag and analytical reagents of $\mathrm{CaO}$ and $\mathrm{P}_{2} \mathrm{O}_{5}$. The chemical composition, which is listed in Table 1, was determined by the slag composition acquired from the previous experiments.

Table 1. Chemical composition of vanadium slag with high $\mathrm{Ca}$ and $\mathrm{P}$ contents wt. \%.

\begin{tabular}{|c|c|c|c|c|c|c|c|c|c|}
\hline $\mathrm{V}_{2} \mathrm{O}_{3}$ & $\mathrm{CaO}$ & $\mathrm{SiO}_{2}$ & $\mathrm{FeO}$ & $\mathrm{TiO}_{2}$ & $\mathrm{MnO}$ & $\mathrm{Al}_{2} \mathrm{O}_{3}$ & $\mathrm{MgO}$ & $\mathrm{P}_{2} \mathrm{O}_{5}$ & else \\
\hline 10.71 & 19.20 & 12.80 & 30.06 & 10.03 & 7.47 & 2.55 & 2.50 & 1.03 & 3.65 \\
\hline
\end{tabular}

It was found from the preliminary experiments that the slag melted when the temperature approached $1400^{\circ} \mathrm{C}$. Hence, the temperature of $1400^{\circ} \mathrm{C}$ was selected as the beginning temperature of blowing oxygen. The experiment was conducted in a vertical high-temperature furnace. Before heating, 80 $\mathrm{g}$ of synthetic slag materials were kept in an alumina crucible and placed at the center of the furnace. The slag materials were heated to $1400^{\circ} \mathrm{C}$ over a period of time. Then, the temperature was held for $5 \mathrm{~min}$ before turning off the power. After that, oxygen was blown immediately into the molten slag at a flow rate of $2 \mathrm{~L} / \mathrm{min}$ through a quartz tube (outer diameter: $8 \mathrm{~mm}$, inner diameter: $4 \mathrm{~mm}$ ). The quartz tube was near but above the slag surface, and oxygen blowing was lasted for $20 \mathrm{~min}$. The clinker was cooled to the room temperature in the furnace.

The clinker was crushed and ground to $<0.074$ $\mathrm{mm}$. Some of them were used for XRD analysis, and the rest were applied for acid leaching. During the leaching process, the slurry was separated via vacuum filtration, and the residues were washed several times by distilled water. All the filtrates were merged. The potassium permanganate oxidationammonium ferrous sulfate titration method was used to measure the concentration of vanadium in the filtrate (YB/T 5328-2006, 2006). The leaching rate of vanadium is expressed as equation (1).

$$
\eta_{\mathrm{V}}=m_{1} / m \times 100
$$

Where $\eta_{\mathrm{v}}$ is the leaching rate of vanadium, $\% ; m_{1}$ is vanadium content in the filtrate, $\mathrm{g} ; m$ is vanadium content in the vanadium slag clinker, $g$.

\section{RESULTS AND DISCUSSION}

\subsection{Mineral phase analysis of the clinker of vanadium slag with high $C a$ and $P$ contents}

As shown in Figure 1, the phases of the clinker mainly include vanadates, silicates, phosphates, titanates and ferric oxides. Most of $\mathrm{V}$ exists in the form of $\mathrm{Ca}_{3} \mathrm{~V}_{2} \mathrm{O}_{8}$, and the rest turns into $\mathrm{Ca}_{0.17} \mathrm{~V}_{2} \mathrm{O}_{5}$ and $\mathrm{CaV}_{2} \mathrm{O}_{5}$. Silicates have many types, mainly including pyroxene phase $\left(\mathrm{Ca}(\mathrm{Mg} / \mathrm{Fe} / \mathrm{Ca}) \mathrm{Si}_{2} \mathrm{O}_{6}\right)$, calcium silicoaluminate phase $\left(\mathrm{CaAl}_{2} \mathrm{Si}_{2} \mathrm{O}_{8}\right)$ and calcium orthosilicate phase $\left(\mathrm{Ca}_{2} \mathrm{SiO}_{4}\right)$. Some of them crystalize later, and the crystal shape is restricted by the space. So, the silicate phases present an irregular particle shape filling the space between other phases and even enwrap other phases. In the subsequent leaching process, those silicates can react with the acid to form colloids which prevent vanadium leaching and result in vanadium loss (Li et al., 2011, 2012; Bie et al., 2010). $\mathrm{P}$ in the clinker exists in the form of $\mathrm{Ca}_{3}\left(\mathrm{PO}_{4}\right)_{2}$. Thus, $\mathrm{P}$ can dissolve into the filtrate together with $\mathrm{V}$ in the leaching process, which can have a disadvantage to purification.

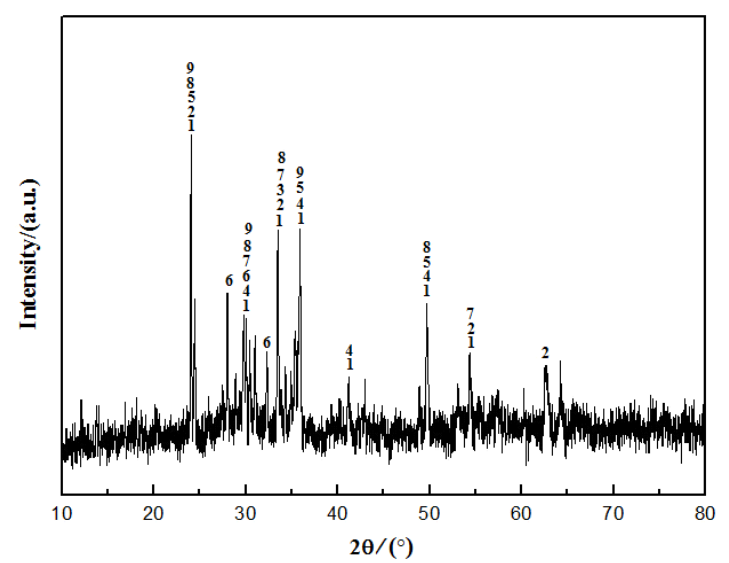

$1-\mathrm{Fe}_{2} \mathrm{O}_{3} ; 2-\mathrm{Fe}_{9} \mathrm{TiO}_{15} ; 3-\mathrm{Ca}_{3}\left(\mathrm{PO}_{4}\right)_{2} ; 4-\mathrm{Ca}(\mathrm{Mg} / \mathrm{Fe} / \mathrm{Ca}) \mathrm{Si}_{2} \mathrm{O}_{6} ; 5-$ $\mathrm{CaAl}_{2} \mathrm{Si}_{2} \mathrm{O}_{8} ; 6-\mathrm{Ca}_{2} \mathrm{SiO}_{4} ; 7-\mathrm{Ca}_{3} \mathrm{~V}_{2} \mathrm{O}_{8} ; 8-\mathrm{CaV}_{2} \mathrm{O}_{5} ; 9-\mathrm{Ca}_{0.17} \mathrm{~V}_{2} \mathrm{O}_{5}$

Figure 1. XRD patterns of the clinker.

\subsection{Effect of acid leaching conditions on vanadium extraction}

\subsubsection{Effect of sulfuric acid concentration}

Calcium vanadate is hardly soluble in water, but it can be easily dissolved in dilute acid. Sulfuric acid is generally chosen as the leaching agent. The leaching conditions are presented in Figure 2. It is apparent that $\eta_{\mathrm{V}}$ increases significantly when the sulfuric acid concentration increases ranging from $5 \%$ to $15 \%$. $\eta_{\mathrm{V}}$ tends to be slightly changed when the sulfuric acid concentration is higher than $15 \%$. Under the circumstance of keeping the ratio of liquid to solid constant, higher acid concentration means more $\mathrm{H}^{+}$ reacting with calcium vanadate, which facilitates vanadium dissolution. However, when the sulfuric acid concentration is too high, excess $\mathrm{H}^{+}$can react with some undesired substances, leading more impurities into the leach liquor, which is detrimental 
to purification. Therefore, the sulfuric acid concentration of $15 \%$ is chosen for further studies.

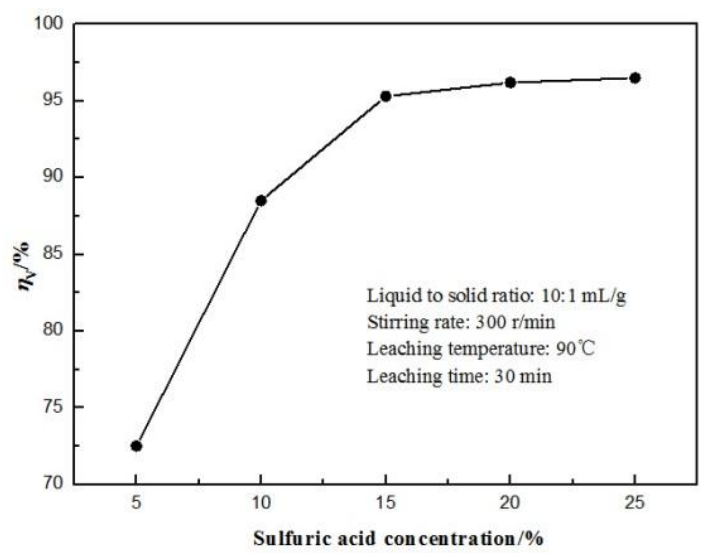

Figure 2. Effect of sulfuric acid concentration on $\eta_{\mathrm{V}}$.

\subsubsection{Effect of liquid to solid ratio}

The relation between $\eta_{\mathrm{V}}$ and liquid to solid ratio and the leaching conditions are all illustrated in Figure 3. A small liquid to solid ratio will lead to a result that the amount of $\mathrm{H}^{+}$is insufficient to fully dissolve calcium vanadate on the condition that the acid concentration is invariant. Besides, the viscosity of the leach liquor becomes high due to the small liquid to solid ratio, which will give rise to a great resistance to the external diffusion of soluble vanadium. Both of them can cause the reduction of $\eta_{\mathrm{V}}$. Figure 3 reveals that $\eta_{\mathrm{V}}$ increases rapidly when the liquid to solid ratio is varied from $2: 1 \mathrm{~mL} / \mathrm{g}$ to $5: 1 \mathrm{~mL} / \mathrm{g}$, but $\eta_{\mathrm{V}}$ has no obvious change with a further increase in the liquid to solid ratio. In addition, a high liquid to solid ratio can dilute the concentration of vanadium, which generates adverse effects on precipitation of vanadium. The liquid to solid ratio is commonly controlled at $(3 \sim 5): 1 \mathrm{~mL} / \mathrm{g}$ in practice production. Considering the discussion above, the ratio of $5: 1 \mathrm{~mL} / \mathrm{g}$ is recommended for the following experiments.

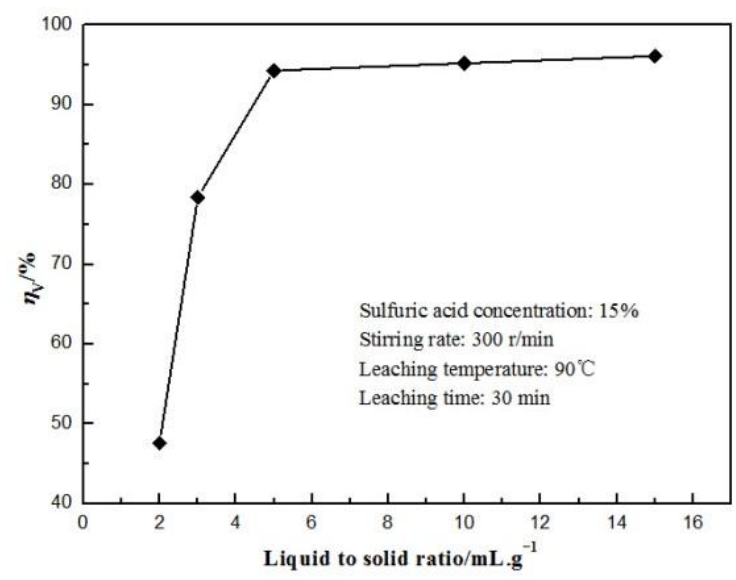

Figure 3. Effect of liquid to solid ratio on $\eta_{\mathrm{V}}$.

\subsubsection{Effect of leaching temperature}

The results shown in Figure 4 suggest that $\eta_{\mathrm{V}}$ increases with an increase in the leaching temperature. One of the reasons is that high temperature can improve the reaction rate. The other is the viscosity of the leach liquor becomes low at high temperature, which can accelerate the diffusion of vanadium. Therefore, the leaching temperature should be as high as possible in practice. But $\eta_{\mathrm{V}}$ negligibly increases with the leaching temperature exceeding $90^{\circ} \mathrm{C}$, furthermore, water is evaporated severely. Hence, $90^{\circ} \mathrm{C}$ is the choice of the leaching temperature.

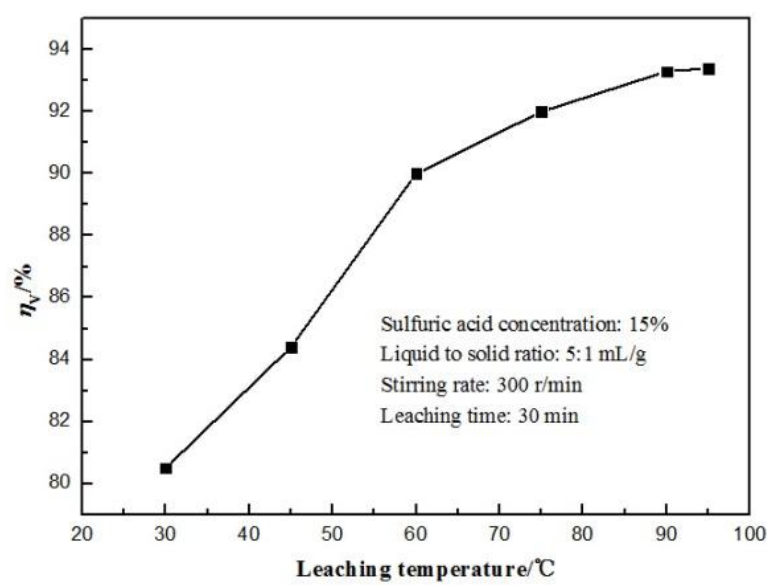

Figure 4. Effect of leaching temperature on $\eta_{\mathrm{v}}$.

\subsubsection{Effect of leaching time}

Figure 5 demonstrates that $\eta_{\mathrm{V}}$ markedly increases with the leaching time from $5 \mathrm{~min}$ up to $40 \mathrm{~min}$. This is because prolonging the leaching time can be of benefit for complete reactions and diffusions occurring in the leaching process. But, with a longer leaching time, $\eta_{\mathrm{V}}$ barely changes observed from Figure 5. So $40 \mathrm{~min}$ is selected as the leaching time.

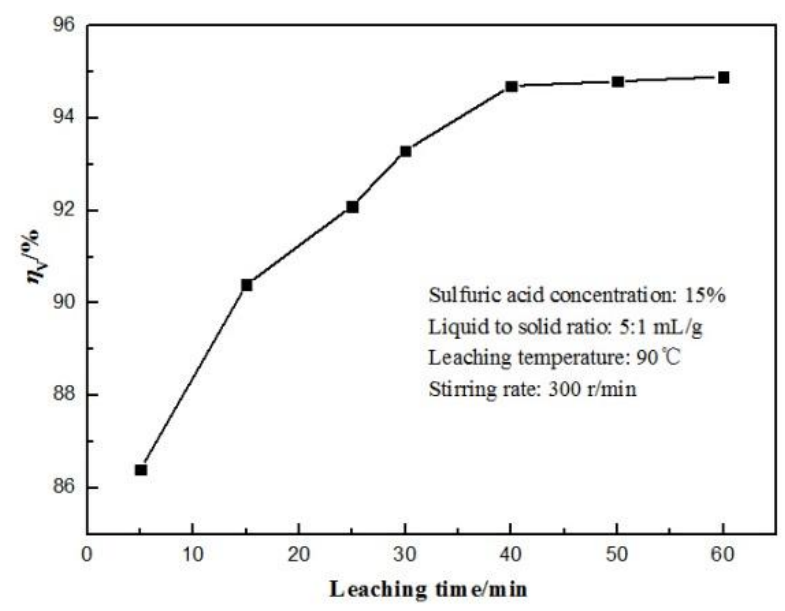

Figure 5. Effect of leaching time on $\eta_{\mathrm{V}}$.

\subsubsection{Effect of stirring rate}

It can be observed from Figure 6 that increasing the stirring rate is beneficial for $\eta_{\mathrm{V}}$. Because stirring can decrease the thickness of the liquid layer on the surface of vanadium slag particle so as to diminish the diffusion resistance. $\eta_{\mathrm{V}}$ nearly increases by $17 \%$ when the stirring rate is varied from $0 \mathrm{r} / \mathrm{min}$ to 240 $\mathrm{r} / \mathrm{min}$, but $\eta_{\mathrm{V}}$ has slight increase with the stirring rate 
above $240 \mathrm{r} / \mathrm{min}$. Thus, the optimum stirring rate under the leaching conditions presented in Figure 6 is $240 \mathrm{r} / \mathrm{min}$.

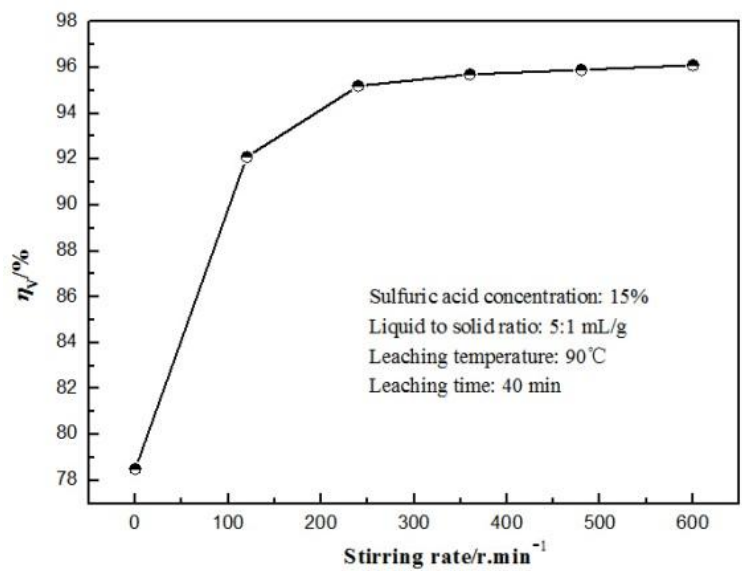

Figure 6. Effect of stirring rate on $\eta_{\mathrm{V}}$.

In summary, the leaching rate of vanadium $\eta_{\mathrm{V}}$ can reach up to $95 \%$ under the optimum leaching conditions: sulfuric acid concentration 15\%, liquid to solid ratio $5: 1 \mathrm{~mL} / \mathrm{g}$, leaching temperature $90^{\circ} \mathrm{C}$, leaching time $40 \mathrm{~min}$, stirring rate $240 \mathrm{r} / \mathrm{min}$.

\subsection{Kinetic analysis of leaching process}

The reactions occurring in the acid leaching process of vanadium slag belong to the typical solid-liquid reaction with a solid product layer formed. The leaching process can be interpreted by the unreacted shrinking core model under the assumption that vanadium slag particle is homogeneously spherical solid phase (Liu et al., 2013). Three established ratecontrolling steps are usually used, and the according equations are expressed as follows (Li, 2005; Yang and Qiu, 1998).

1) Surface reaction control

$$
1-\left(1-\eta_{\mathrm{V}}\right)^{1 / 3}=k_{1} t
$$

2) Internal diffusion control (Solid product layer control)

$$
1-2 / 3 \eta_{\mathrm{V}}-\left(1-\eta_{\mathrm{V}}\right)^{2 / 3}=k_{2} t
$$

3) External diffusion control (Liquid boundary layer diffusion control)

$$
\eta_{\mathrm{V}}=k_{3} t
$$

Where $k_{1}, k_{2}$ and $k_{3}$ are the rate constants, $\min ^{-1} ; t$ is the leaching time, min.

In order to determine the controlling step in the leaching process of vanadium slag, the data of $\eta_{\mathrm{V}}$ at different leaching temperatures were fitted using equations (2), (3) and 4), and the corresponding results are given in Figure 7, Figure 8 and Figure 9, respectively. The slopes of the fitted lines are the numerical values of $k_{1}, k_{2}, k_{3}$, respectively, as shown in Table 2.

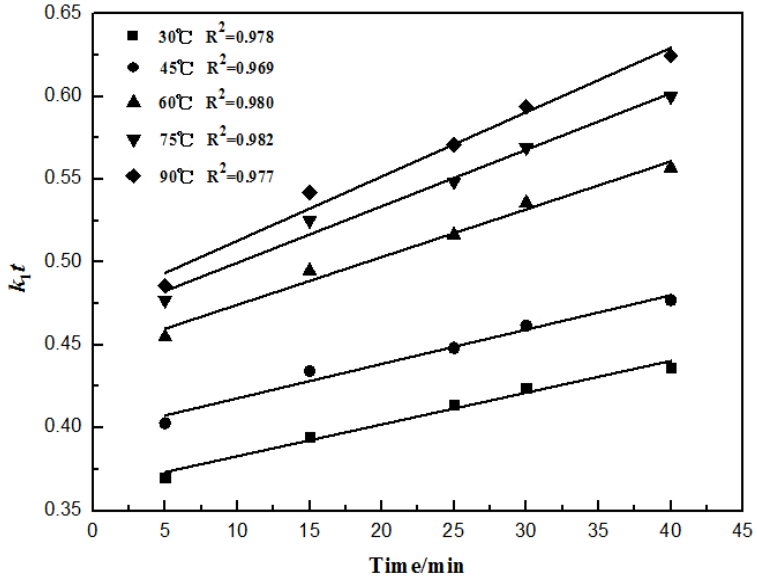

Figure 7. Fitted results of $\eta_{\mathrm{V}}$ data by equation of surface reaction control at different temperatures.

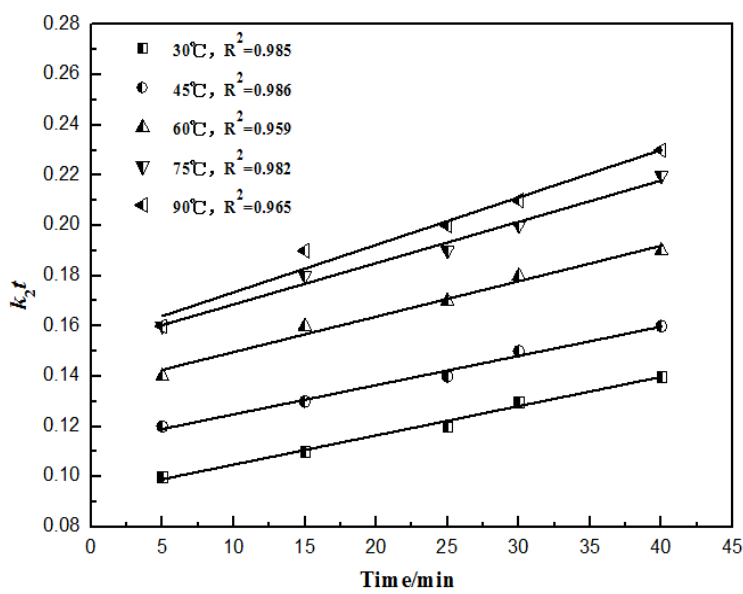

Figure 8. Fitted results of $\eta_{\mathrm{V}}$ data by equation of internal diffusion control at different temperatures.

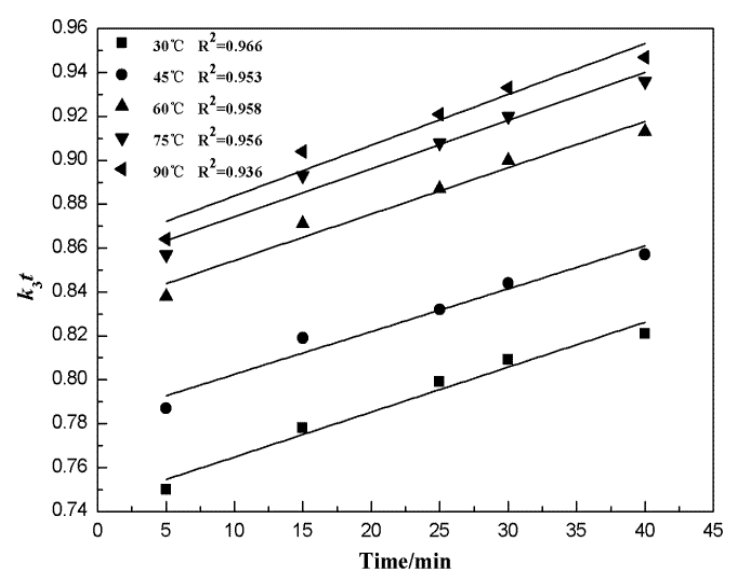

Figure 9 Fitted results of $\eta_{\mathrm{V}}$ data by equation of external diffusion control at different temperatures

The apparent activation energy can be calculated based on the Arrhenius equation which is expressed as follow. The relation between natural logarithm of the rate constant $(\ln k)$ and the leaching temperature $(T)$ is obtained as a function of Table 2 , as plotted in Figure 10.

$$
\ln k=\ln \mathrm{A}-E \mathrm{a} / R T
$$


Where $k$ is the rate constant; $\mathrm{A}$ is the preexponential factor; $E \mathrm{a}$ is the apparent activation energy, $\mathrm{J} / \mathrm{mol} ; R$ is the molar gas constant, $\mathrm{J} /(\mathrm{mol} \cdot \mathrm{K}) ; T$ is the leaching temperature, $\mathrm{K}$.

Table 2. Results of $k_{1}, k_{2}, k_{3}$ and $\ln k_{1}, \ln k_{2}, \ln k_{3}$.

\begin{tabular}{|c|c|c|c|c|c|c|}
\hline $1 / T \times 10^{3} / \mathrm{K}^{-1}$ & $k_{1}$ & $\ln k_{1}$ & $k_{2}$ & $\ln k_{2}$ & $k_{3}$ & $\ln k_{3}$ \\
\hline 3.300 & 0.0019 & -6.266 & 0.0011 & -6.812 & 0.0021 & -6.166 \\
\hline 3.145 & 0.0021 & -6.166 & 0.0012 & -6.725 & 0.0020 & -6.215 \\
\hline 3.003 & 0.0029 & -5.843 & 0.0014 & -6.571 & 0.0021 & -6.166 \\
\hline 2.874 & 0.0034 & -5.684 & 0.0016 & -6.438 & 0.0022 & -6.119 \\
\hline 2.755 & 0.0039 & -5.547 & 0.0019 & -6.266 & 0.0023 & -6.075 \\
\hline
\end{tabular}

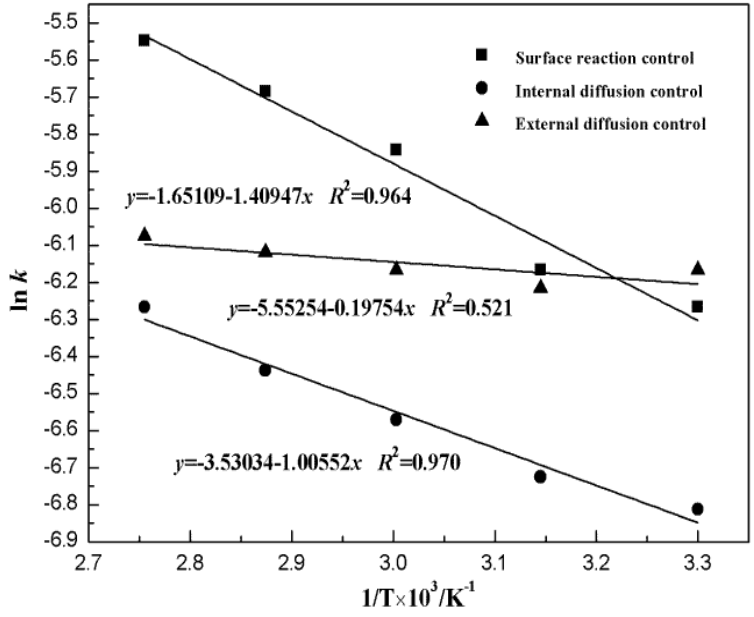

Figure 10. The relation between $\ln k$ and $T$.

It can be calculated from Figure 10 that the apparent activation energies are $11.72 \mathrm{~kJ} / \mathrm{mol}$, $8.36 \mathrm{~kJ} / \mathrm{mol}$ and $1.64 \mathrm{~kJ} / \mathrm{mol}$ when the rate-controlling steps are surface reaction step, internal diffusion step and external diffusion step, respectively. However, the apparent activation energy should be greater than $41.8 \mathrm{~kJ} / \mathrm{mol}$ when surface reaction step is the ratecontrolling step, and the apparent activation energy should be $4 \sim 12 \mathrm{~kJ} / \mathrm{mol}$ when diffusion step is the rate-controlling step. Therefore, the possibilities that the rate-controlling step is surface reaction step or external diffusion step are excluded. In view of the discussion above, the rate-controlling step in the acid leaching process of vanadium slag is internal diffusion, and the apparent activation energy is 8.36 $\mathrm{kJ} / \mathrm{mol}$.

\section{CONCLUSIONS}

The main mineral phases of the clinker of vanadium slag with high $\mathrm{Ca}$ and $\mathrm{P}$ contents include vanadates, silicates, phosphates, titanates and ferric oxides. Most of $\mathrm{V}$ exists in the form of $\mathrm{Ca}_{3} \mathrm{~V}_{2} \mathrm{O}_{8}$, the rest changes into $\mathrm{Ca}_{0.17} \mathrm{~V}_{2} \mathrm{O}_{5}$ and $\mathrm{CaV}_{2} \mathrm{O}_{5}$. Silicate phases mainly consist of pyroxene, calcium silicoaluminate and calcium orthosilicate, some of which will prevent vanadium leaching and result in vanadium loss in the subsequent leaching process. $\mathrm{P}$ in the clinker exists in the form of $\mathrm{Ca}_{3}\left(\mathrm{PO}_{4}\right)_{2}$, so $\mathrm{P}$ can dissolve into the filtrate with $\mathrm{V}$ and generate a disadvantage to purification. The leaching rate of vanadium can reach up to $95 \%$ under the optimum leaching conditions: sulfuric acid concentration $15 \%$, liquid to solid ratio $5: 1 \mathrm{~mL} / \mathrm{g}$, leaching temperature $90^{\circ} \mathrm{C}$, leaching time $40 \mathrm{~min}$, stirring rate 240r/min. The rate-controlling step in the acid leaching process of vanadium slag is internal diffusion, and the corresponding apparent activation energy is $8.36 \mathrm{~kJ} / \mathrm{mol}$.

\section{ACKNOWLEDGMENTS}

The financial support of the Independent Research Program of State Key Laboratory of Advanced Metallurgy (University of Science and Technology Beijing) (No. 41603004) for this work is gratefully acknowledged.

\section{REFERENCES}

[1] Bie, S., Wang, Z.J., Li, Q.H., Zhang, Y.G. 2010. Review of vanadium extraction from stone coal by roasting technique with sodium chloride and calcium oxide. Chinese Journal of Rare Metals 34(2): 291-297.

[2] Dong, P.Q. 1997. Current situation of the converter semisteel steelmaking technology in China. Steelmaking 13(2): 62-64.

[3] Fu, Z.B. 2011. Development process and trends of vanadium extraction from vanadium-titanium magnetite ore. China Nonferrous Metallurgy 40(6): 29-33.

[4] Li, H., Song, W.C., Niu, S.T., Niu, S.Z., Guo, L.F. 2012. A method of dealing with vanadium slag with energy conservation and emission reduction. Chinese Patent (ZL201110044380 .5).

[5] Li, H.G. 2005. Hydrometallurgy. Changsha: Central South University Press, 74.

[6] Li, K., Song, W.C., Zheng, Q., Li, H. 2013. Vanadium extraction by acid leaching after calcification of molten vanadium slag. Iron Steel Vanadium Titanium 34(5): 1518.

[7] Li, X.J., Xie, B., Diao, J., Zhang, C.Y.,Wang, Y.H. 2011. Kinetic of isothermal growth of spinel in vanadium slag. Chinese Journal of Rare Metals 35(2): 281-285.

[8] Li, X.J., Zhang, R.P., Xie, B. 2012. Effect of vanadiumcontaining slag calcium roasting conditions on leaching rate of vanadium. The Chinese Journal of Process Engineering 12(1): 54-58. 
[9] Liu, H.B., Du, H., Wang, D.W., Wang, S.N., Zheng, S.L., Zhang, Y. 2013. Kinetics analysis of decomposition of vanadium slag by $\mathrm{KOH}$ sub-molten salt method. Transactions of Nonferrous Metals Society of China 23(5): 1489-1500.

[10] Song, W.C., Li, H., Li, K., Zheng, Q. 2013. New process of vanadium extraction from molten vanadium slag. Nonferrous Metals (Extractive Metallurgy) (7): 35-37.

[11] Song, W.C., Li, K., Zheng, Q., Li, H. 2014. A novel process of vanadium extraction from molten vanadium bearing slag. Waste and Biomass Valorization 5(3): $327-$ 332.
[12] Yang, X.W., Qiu, D.F. 1988. Hydrometallurgy. Beijing: Metallurgical Industry Press, 174.

[13] YB/T 5328-2006. 2006. The potassium permanganate oxidation-ammonium ferrous sulfate titrimetric method for the determination of vanadium pentoxide content. Beijing: Standards Press of China.

[14] Zhang, Y.L., Zhao, F., Wang, Y.G. 2011. Effects of influencing factors on distribution behaviors of vanadium between hot metal and $\mathrm{FeO}-\mathrm{SiO} 2-\mathrm{MgO}$ (-TiO2) slag system. Steel Research International 82(8): 940-950. 